\title{
IMPLEMENTASI BALANCE SCORECARD PADA PERUSAHAAN JASA PERHOTELAN : STUDI KASUS PADA PT. HOTEL X DI SEMARANG
}

\begin{abstract}
Balanced Scorecard merupakan suatu sistem manajemen strategis yang mengukur kinerja perusahaan melalui empat perspektif, yaitu perspektif keuangan, perspektif pelanggan, perspektif proses bisnis internal, dan perspektif pembelajaran dan pertumbuhan. Penelitian ini bertujuan untuk mengetahui tingkat keberhasilan kinerja suatu perusahaan dengan menggunakan konsep BSC yang diimplementasikan pada perusahaan jasa yang bergerak di bidang pariwisata, yaitu perhotelan. Data yang digunakan dalam pnelitian ini berupa data primer dan sekunder. Data primer, pengumpulan data dilakukan menggunakan kuesioner dengan sampel sebanyak 53 responden. Hasil penelitian inimenunjukkan bahwa dengan menerapkan Balanced Scorecard maka pihakmanajemen mendapatkan hasil yang komprehensif. Hal ini dapat dilihat bahwa perusahaan selain dapat mengelola pendapatan dan biaya yang dikeluarkan secara optimal, kepuasan pelanggan, pengembangan produk, serta kepuasan karyawan atas kinerja perusahaan dapat terpenuhi dan hasil penelitian dapat disimpulkan bahwa kinerja perusahaan yang diukur melalui empat perspektif dalam balanced scorecard sudah tergolong baik dan kinerja perusahaan mencapai tingkat yang memuaskan.
\end{abstract}

Keywords: Balanced Scorecard, perspektif keuangan, perspektif pelanggan, perspektif proses bisnis internal, dan perspektif pembelajaran dan pertumbuhan

\section{PENDAHULUAN}

Industri perhotelan menjadi industri yang bersifat global dan "mature", sehingga dihadapkan pada kompetisi yang sangat kuat. Untuk mendapatkan keunggulan kompetitif, maka setiap perusahaan dituntut untuk mampu memuaskan konsumennya. Perusahaan berupaya untuk meningkatkan kualitas pelayanan melalui kepuasan pelanggan yang dilakukan secara terus-menerus.

Salah satu aspek penting dalam mempertahankan kelangsungan hidup perusahaannya adalah dengan memperbaiki mekanisme dan perumusan sistem pengukuran kinerja. Pengukuran kinerja bukan saja dipandang dari sisi keuangan saja tetapi juga non keuangan seperti proses bisnis internal, kapabilitas dan komitmen personelnya. Pengukuran kinerja yang hanya berdasarkan kinerja keuangan memiliki kelemahan, yaitu tidak mampu untuk mempresentasikan kinerja aktiva tak berwujud (intangible asset) dalam laporan keuangan secara memadai, padahal struktur harta/ aset perusahaan justru didominasi oleh aktiva tak berwujud yang merupakan harta-harta intelektual seperti sistem, teknologi, skill, enter-preneurship karyawan, loyalitas konsumen, kultur organisasi, dan kepuasan pelanggan. Untuk mengukur kinerja organisasi di masa depan, diperlukan suatu ukuran-ukuran yang lebih komprehensif yaitu Balanced Scorecard (BSC). BSC memiliki keistimewaan dalam hal cakupan pengukurannya yang cukup komprehensif karena selain tetap mempertimbangkan kinerja keuangan. BSC juga mempertimbangkan kinerja-kinerja non keuangan, yaitu pelanggan, proses internal bisnis, 
serta pembelajaran dan pertumbuhan yang dapat digunakan. Disamping itu, BSC dapat digunakan sebagai sarana komunikasi, informasi, dan proses belajar dalam suatu perusahaan, serta mengarahkan upaya pencapaian tujuan perusahaan kepada karyawan. Sumber daya manusia merupakan salah satu dari beberapa faktor produksi yang penting yang terdapat di perusahaan, dan bagaimana peran pimpinan perusahan untuk menciptakan karyawan yang berkembang kreatif, inovatif, dan produktif, sehingga produktivitas kerja bagi karyawan dapat tercapai. Hal ini dimaksudkan untuk melakukan inovasi dan menciptakan pertumbuhan dan peningkatan kinerja jangka panjang. Sistem pengukuran kinerja dengan menggunakan pendekatan BSC bersifat komprehensif, meliputi empat perspektif, yaitu keuangan, pelanggan, proses bisnis internal, serta pembelajaran dan pertumbuhan. Oleh karena itu BSC dapat membantu manajemen dalam menentukan tingkat keberhasilan perusahaan baik dalam jangka pendek, jangka menengah, maupun jangka panjang.

\section{KAJIAN PUSTAKA}

BSC merupakan suatu sistem pengukuran taktis atau operasional untuk mengelola strategi jangka panjang dan menghasilkan berbagai proses manajemen penting, yaitu sebagai berikut :

1. Memperjelas dan menerjemahkan visi dan strategi.

2. Memperjelas dan menerjemahkan visi dan strategi.

3. Merencanakan, menetapkan sasaran, dan menyelaraskan berbagai inisiatif strategis.

4. Merencanakan, menetapkan sasaran, dan menyelaraskan berbagai inisiatif strategis.

BSC menerjemahkan misi dan strategi ke dalam berbagai tujuan dan ukuran, yang tersusun ke dalam empat perspektif, yaitu keuangan, pelanggan, proses bisnis internal, dan pembelajaran dan pertumbuhan.

Ukuran kinerja finansial memberikan petunjuk apakah strategi perusahaan, implementasi dan pelaksanaannya dapat memberikan kontribusi peningkatan laba perusahaan. Tujuan finansial berhubungan dengan profitabilitas, yang diukur misal oleh laba operasi, return on capital employed (ROCE), dan nilai tambah ekonomis (economic value added).

Perspektif pelanggan, untuk mencapai kinerja keuangan yang baik dalam jangka panjang, perusahaan harus menciptakan dan menyediakan produk dan jasa yang mempunyai nilai bagi konsumen, yaitu manfaat yang diterima konsumen relatif lebih tinggi daripada pengorbanan yang dikeluarkan.

Perspektif proses bisnis internal, manajer harus mengidentifikasikan proses-proses yang paling kritis untuk mencapai tujuan peningkatan nilai bagi pelanggan dan tujuan peningkatan nilai bagi pemegang saham.Perusahaan harus memilih proses dan kompetensi yang menjadi unggulannya dan menentukan ukuran-ukuran untuk menilai kinerja terhadap proses dan kompetensi tersebut.

Perspektif pembelajaran dan pertumbuhan adalah memberikan infrastruktur yang memungkinkan tujuan dalam ketiga perspektif lainnya dapat tercapai.

\section{METODE PENELITIAN}

Populasi dalam penelitian ini berjumlah 53 karyawan yang bekerja sebagai karyawan tetap yang merupakan karyawan kunci di PT. Hotel X terbagi dalam beberapa bagian, yaitu: 12 orang di bagian 
Front Office, 18 orang di bagian Food and Beverage, 18 orang di bagian House Keeping, 5 orang di bagian Accounting.

Mengingat populasi yang berjumlah 53 karyawan yang bekerja sebagai karyawan tetap di PT. Hotel X di Semarang, maka dalam penelitian ini semua populasi menjadi responden.

Data yang digunakan dalam penelitian ini adalah data primer dan sekunder. Untuk data primer, metode pengumpulan menggunakan kuesioner dengan menggunakan skala Likert, sedang data sekunder berupa laporan keuangan yang terdiri dari neraca dan laporan laba-rugi, dan data-data yang menyangkut perspektif pelanggan (market share, customer satisfaction), proses bisnis internal, dan pembelajaran dan pertumbuhan. Kualitas data yang dihasilkan dari penggunaan instrumen penelitian dapat dievaluasi melalui uji validitas dan uji reliabilitas.

\section{HASIL DAN PEMBAHASAN}

Penilaian BSC didasarkan pada penetapan rentang target yang ditetapkan oleh PT. Hotel X di Semarang, sebagai berikut:

\section{Perspektif Keuangan}

Berdasarkan Rasio ROI, pada tahun 2011 sampai dengan tahun 2013 diperoleh ROI sebesar 11,50 $\%$, 9,98 \% dan 14,93 \%. Hasil ini menunjukkan bahwa perusahaan telah berupaya dalam memaksimalkan penggunaan aktiva untuk memperoleh tingkat pengembalian yang tinggi, sehingga dapat dikategorikan baik.

Berdasarkan Ratio Operasi pada tahun 2011 sampai dengan tahun 2013 sebesar 63,65 \%, 67,19 $\%$ dan 62,25 \%. Rasio operasi menggambarkan biaya operasi yang dikeluarkan perusahaan per rupiah penjualan jasanya. Besarnya ratio operasi diperoleh dari perbandingan antara total HPP dan biaya operasi dengan total pendapatan. Makin besar ratio operasi berarti kinerja perusahaan makin buruk. Berdasarkan data tersebut menunjukkan bahwa perusahaan dapat menekan biaya yang dikeluarkan untuk penjualan jasanya dan memperoleh pendapatan yang cukup besar, sehingga dikategorikan baik.

Tingkat pertumbuhan pendapatan memperlihatkan perkembangan usaha dari tahun ke tahun. Besarnya tingkat pertumbuhan pendapatan diperoleh dari selisih pendapatan tahun ini dengan pendapatan tahun kemarin terhadap pendapatan tahun kemarin. Semakin besar tingkat pertumbuhan pendapatan, maka kinerja perusahaan semakin baik.

Tingkat pertumbuhan pendapatan pada tahun 2012 sebesar18,63 \% dan tahun 2013 sebesar 42,92 \%. dapat diketahui bahwa tingkat pertumbuhan pendapatan PT. Hotel X sudah baik, hal ini disebabkan karena adanya publikasi, yang mengakibatkan peningkatan pendapatan baik room revenue maupun non room revenue.

2. Perspektif Pelanggan

Variabel yang dijadikan tolok ukur kinerja adalah sebagai berikut Market Share dan Kepuasan pelanggan. profitabilitas pelanggan dan Occupancy room 
Market share tahun 2011 sampai dengan tahun 2013 sebesar 8,35\%, 9,90\% dan 10,18\%. Hal ini menunjukkan bahwa market share PT. Hotel X sudah baik yang ditunjukkan setiap tahun terjadi market share PT. Hotel Grasia sudah sangat baik, karena tiap tahun mengalami peningkatan peningkatan.

Berdasarkan kepuasan pelanggan meliputi kenyamanan, keramahan, kecepatan, tanggap, rasa masakan, dan keamanan. Hasil yang diperoleh rata-rata di atas 50\%, kecuali untuk atribut rasa masakan yang turun menjadi 40\% pada tahun 2012.

Profitabilitas pelanggan yang dicapai dari tahun 2011 sampai dengan tahun 2013 sebesar 59,72\%, $67,95 \%$ dan 68,87\%. Hal ini menunjukkan bahwa standar yang ditetapkan dikategorikan baik.

Occupancy room dari tahun 2011 sampai dengan tahun 2013 sebesar 52,43\%, 50,19\% dan 53,33\%. Occupancy room menunjukkan tingkat hunian suatu hotel yaitu dengan mengetahui jumlah kamar yang terjual (Room Night Occupied/ RNO) dari jumlah kamar yang tersedia (Room Night Available/ RNA). Dengan demikian dapat dikatakan bahwa tingkat hunian PT. Hotel X menurut standar yang telah ditetapkan dikategorikan baik.

3. Perspektif Proses Bisnis Internal

Dalam perspektif proses bisnis internal terdapat tiga variabel yang diperhitungkan, yaitu proses inovasi, proses operasi dan layanan purna jual. Proses inovasi diperoleh dari perbandingan antara jasa baru yang ditawarkan dengan total jasa yang ditawarkan. Tingkat inovasi PT. Hotel X mencapai 3,16\% pada tahun 2012 dan 2,06\% pada tahun 2013. Ini berarti bahwa PT. Hotel X selalu berusaha memuaskan kebutuhan konsumennya dengan cara melakukan penambahan fasilitas.

Bagi perusahaan jasa, waste time merupakan hal yang penting untuk dieliminasi dalam kegiatan operasionalnya jika dibandingkan dengan perusahaan manufaktur. Khusus bagi jasa perhotelan, semua aspek kegiatan mulai dari chek-in sampai check-out memungkinkan adanya customer value. Oleh sebab itu, waktu cycle yang panjang dalam pelayanan kepada konsumen sedapat mungkin dihindari. Waktu check-in yang dibutuhkan adalah 5 menit untuk pemrosesan. Waktu yang dibutuhkan untuk memberikan service adalah 10 menit yang dimulai dengan pengaksesan jasa yang diminta konsumen sampai dengan selesainya proses pengiriman jasa. Waktu yang diperlukan untuk proses check-out adalah 10 menit.

Cycle effectiveness PT. Hotel X diperoleh dari perbandingan antara waktu proses dengan throughput time. Dalam penjualan jasa, PT. Hotel X bekerja selama satu bulan penuh dan 24 jam per hari, sehingga diperoleh cycle effectiveness sebesar 0,057\%. Hal ini menurut target yang ditetapkan bahwa untuk waktu check-in dan waktu check-out sudah baik, tetapi untuk waktu service masih kurang.

Layanan purna jual merupakan proses setelah proses operasi dilakukan. Besarnya prosentase layanan purna jual diperoleh dari perbandingan antara jumlah keluhan yang tertangani dengan jumlah keseluruhan keluhan. Semakin sedikit total jumlah keluhan, berarti pelanggan merasa puas dengan pelayanan yang diberikan oleh pihak hotel. Berdasarkan data menunjukkan bahwa hotel mampu menangani semua keluhan tamu (100\% tertangani) dan jumlah keluhan pada tahun 2012 menurun, walaupun terjadi peningkatan yang kecil sekali pada tahun 2013. Ini dibuktikan dengan tindakan yang diambil perusahaan dalam menanggapi keluhan konsumen, yaitu apabila terdapat ketidakpuasan konsumen atas pelayanan yang diberikan PT. Hotel 
$X$ dan ketidakpuasan ini disebabkan karena kesalahan pihak hotel, maka pihak hotel akan memberikan ganti rugi berupa diskon (potongan harga) atau konsumen dapat menempati kamar yang kelasnya lebih tinggi daripada yang dipesan tetapi dengan harga kamar yang dipesan. Hal ini dilakukan untuk tetap menjaga image dan kualitas hotel dimata konsumen, sehingga menurut standar yang ditetapkan PT. Hotel X dikategorikan sangat baik.

\section{Perspektif Pembelajaran dan Pertumbuhan}

Pengukuran perspektif pembelajaran dan pertumbuhan terdapat tiga pengukuran, yaitu tingkat perputaran karyawan, tingkat produktivitas karyawan dan kepuasan karyawan.

\section{Tingkat perputaran karyawan}

Tingkat perputaran karyawan menunjukkan seberapa besar kemampuan perusahaan untuk mempertahankan karyawan-karyawannya dalam jangka panjang dan besarnya tingkat perputaran karyawan diperoleh dari perbandingan antara jumlah karyawan yang keluar dengan jumlah karyawan seluruhnya. Semakin sedikit karyawan yang mengundurkan diri/ keluar maka semakin baik tingkat perputaran karyawannya. Pada tahun 2012 ada 2 karyawan yang keluar dan 1 karyawan pada tahun 2013. Dengan demikian dapat dikatakan bahwa perusahaan sudah baik dalam mempertahankan karyawannya walaupun setiap tahunnya ada karyawan yang keluar

\section{Tingkat produktivitas}

Tingkat produktivitas karyawan ditunjukkan dengan perbandingan antara penjualan yang diperoleh perusahaan dengan jumlah total karyawan pada tahun berjalan. Semakin besar penjualan yang dihasilkan oleh setiap karyawan, maka menunjukkan bahwa tingkat produktivitas karyawannya semakin baik. Tingkat produktivitas karyawan yang dicapai PT. Hotel X dari tahun 2011 sampai dengan tahun 2013 terjadi peningkatan yaitu sebesar Rp. 13.058.966,00 pada tahun 2012 dan sebesar Rp.31.829.097,00 pada tahun 2013. Dengan demikian tingkat produktivitas sangat baik karena mampu mempertahankan karyawan kunci yang merupakan sebagai penggerak organisasi.

\section{Kepuasan karyawan.}

Kepuasan karyawan merupakan faktor yang mempengaruhi tingkat perputaran karyawan dan produktivitas karyawan. Semakin tinggi tingkat kepuasan karyawan, maka semakin tingkat perputaran dan tingkat produktivitas karyawan. Tingkat kepuasan karyawan sudah mencapai taraf yang cukup memuaskan yang yang diukur dari kebijakan perusahaan, motivasi dan semangat kerja, akses informasi dan komunikasi, kondisi fisik tempat kerja, dan kepemimpinan, walaupun terdapat rasa kurang puas dari karyawan terhadap manajemen perusahaan 


\section{Analisis Balanced Scorecard}

Berdasarkan perhitungan dengan menggunakan BSC dapat diketahui bahwa skor kinerja PT. Hotel X adalah sebesar 150 atau skor berada di kisaran 101-150 yang bisa dikatakan pada kondisi yang baik. Tetapi terdapat nilai kurang pada waktu proses pelayanan yang diberikan oleh perusahaan kepada kepuasan pelanggan (tamu hotel), occupancy room, dan kepuasan karyawan terhadap manajemen perusahaan. Hal ini yang menyebabkan pelanggan (tamu hotel) kurang merasa puas karena waktu proses pelayanan yang lama, misalnya bellboy tidak selalu stand by ketika tamu datang, oleh karenanya receptionist harus memanggil bellboy terlebih dahulu sehingga tamu harus menunggu dalam waktu tertentu. Ketidakpuasan juga terjadi karena kurang ramahnya karyawan perusahaan khususnya karyawan yang bekerja di bagian front office. Padahal keramahan bisa membuat pelanggan merasa nyaman sehingga tercipta rasa puas.

Selain rasa ketidakpuasan pelanggan terhadap pelayanan yang mempunyai nilai kurang, occupancy room (tingkat hunian kamar) juga mempunyai nilai kurang. Banyaknya pesaing membuat tingkat hunian kamar Hotel X terlihat rendah. Hal ini disebabkan karena banyaknya hotel-hotel baru di Semarang dengan fasilitas room dan non room yang bervariasi, padahal menurut pihak hotel tingkat pertumbuhan tamu hotel di Semarang sekitar $7 \%$ per tahun. Hal ini berarti tingkat pertumbuhan jumlah kamar hotel tidak sebanding dengan tingkat pertumbuhan tamu hotel.

Di samping itu nilai kurang juga terjadi pada karyawan yang merasa kurang puas terhadap manajemen perusahaan. Ini disebabkan karena PT. Hotel X merupakan perusahaan keluarga, sehingga tidak semua keputusan manajemen perusahaan menjadi informasi publik maupun karyawan, sehingga banyak kebijakan dibahas hanya pada level manajemen. Hanya kebijakan yang bersifat general yang diketahui karyawan.

\section{PENUTUP / SIMPULAN}

1. Ditinjau dari perspektif keuangan PT. Hotel X selama tiga tahun terakhir ini sudah baik dan menunjukkan adanya efisiensi antara pengelolaan aktiva, biaya yang dikeluarkan, dan pendapatan yang terima.

2. Ditinjau dari perspektif pelanggan sudah cukup baik meskipun terdapat pelanggan yang merasa kurang puas dengan pelayanan yang diberikan oleh PT. Hotel X.

3. Ditinjau dari perspektif proses internal sudah baik., tetapi jika dilihat dari tingkat cycle effectiveness yang sebesar $0.057 \%$ dirasa masih kurang baik, karena hal ini dipengaruhi oleh waktu proses pelayanan masih kurang baik.

4. Ditinjau dari perspektif pembelajaran dan pertumbuhan tergolong sangat baik. Hal ini terbukti perusahaan dapat mempertahankan karyawan kunci yang bekerja di perusahaan walaupun terdapat rasa kurang puas dari karyawan terhadap manajemen perusahaan.

\section{Saran}

Pentingnya peningkatan kualitas pelayanan agar tercipta loyalitas pelanggan yang nantinya akan mendukung pencapaian target pendapatan dengan keramahan karyawan khususnya yang bekerja di bagian front office. 
Fasilitas room dan non room lebih ditingkatkan lagi mengingat banyaknya perusahaan pesaing yang mempunyai fasilitas-fasilitas yang lebih bervariasi.

\section{DAFTAR PUSTAKA}

Gaspersz, V. (2002). Sistem Manajemen Kinerja Terintegrasi: Balanced scorecard dengan Six Sigma untuk Organisasi Bisnis dan Pemerintah. Jakarta: PT. Gramedia Pustaka Utama

Gumbus, A., Lussier, R. N. (2006). Entrepreneurs Use a Balanced scorecard to Translate Strategy into Performance. ProQuest. 11-14.

Kaplan, R. S., Norton, D. P. (1992). The Balanced scorecard - Measures that Drive Performance.

Harvard Business Review . (1996). The Balanced scorecard:Translating Strategy into Action. Harvard Business School. c.336p.

Kaplan, R. S. (2010). Conceptual Foundations of the Balanced scorecard. Harvard Business School Working Paper. 10-074 1040 ComTech Vol. $5 \quad$ No. 2 Desember 2014: 1031-1040

Kementrian Keuangan RI. (2012). Kajian Profil Sektor Riil : Sektor Perdagangan, Hotel, dan Restoran.

. Rompho, N. (2011). Why the Balanced scorecard Fails in SMEs: A Case Study. International Journal of Business and Management. 6(11): 39-46

Wyatt, J. (2004). Scorecards, Dashboards, and KPIs: Keys to Integrated Performance Measurement.

ProQuest Nursing \& Allied Health Source. $\quad$ 58(2): 76-80

Yuwono, S., Sukarno, E., Ichsan, M. (2007). Petunjuk Praktis Penyusunan Balanced Scorecard Menuju Organisasi yang Berfokus pada Strategi.Edisi $\quad$ 4. Jakarta:PT Gramedia Pustaka Utama. 